\title{
甲状腺性侏儒症について
}

\author{
益田赤十字病院整形外科

大 橋 清秀

鳥取大学整形外科

上平用

\section{Clinical Studies of Hypothyroid Dwarfism}

\author{
By \\ K. Ohashi \\ Orthopedic Clinic, Masuda Red Cross Hospital \\ M. Kamihira \\ Department of Orthopedic Surgery, Tottori \\ University School of Medicine
}

The present report offers the result of our studies on various clinical observations and the effect of treatments about 23 cases diagnosed as hypothyroid dwarfism, including 5 cases of acquired hypothyroidism. Endocrine function test; In each of the cases of hypothyroid dwarfism, there is a tendency of serum cholesterol to increase and for protein-bound iodine to decrease. The ${ }^{131} \mathrm{I}$ uptake level is lower than control in many cases, while that of primary hypothyroid dwarfism remarkably goes down with no respons to T. S. H-test. Through the electroencephalography, the blood sugger test, the water test and the insuline test, abnormal signs and hypofunction were found. About pituitary-adrenocortical function, the measurements of urinary $17-\mathrm{KS}$ and 17-OHCS tell us that in hypothyroid dwarfism it is far below normal. Those clinical observations suggest that hypothyroid dwarfism may be influenced by functional hypofunction of pituitary gland.

Roentogenograms; The retardation in skeletal growth is found in all cases, but the structure of skeleton is not seen morphologically.

In addition to the very slow development in bone age, hypothyroid dwarfism shows punctuated epiphyseal dysgenesis symmetrically on both sides, which is typically noted in the hip. This dysgenesis, which helps us diagnosis of hypothyroidismus, is observed on the patient who has fellen ill before the epiphyseal ossification centers appear.

By the fact, we can conclude chronological age of the patient who has fallen ill.

Treatments and results; The effect of treatments with thyroid hormone were excellent in relieving hypothyroid dwarfism. The first finding of the effect remarkably appeared in bone age and following to it is weight age and height age but not so much as bone age. Mental development was far bellow normal.

The effect of treatments were influenced by the age who has fallen ill (congenital or acquired), degree of hypofunction of thyroid gland, functional hypofunction of pituitary gland, and various divices of the treatments.

近年, 内分泌機能検査法が発達し, 今まで原因不明 とされていた骨系統疾患のなかには, 明らかに内分泌 機能異常をみいだすばかりか, Radioimmunoassay により,ホルモンの定量む可能になったことなどから， 内分泌障害による骨成長異常も骨系統疾患として重要
な位置を占めるようになったといえる.われわれは発 育期に甲状腺機能低下を確認し得た症例について, 治 療効果を検討した結果, 若干の知見を得たので報告す る.

昭和 46 年 12 月末までにわれわれの教室に登録され 
た骨系統疾患々者は 229 例に達した. 内分泌機能障害 亿基因する 症例は 88 例で，乙のうち甲状腺機能低下 症を確認し得たのは 23 例であった。男女別にみる 之, 男 13 例, 女 10 例, 年令別では 5 才未満 2 例, 5 $\sim 9$ 才 9 例, 10 14才 7 例, 15 19才 4 例, 20 才以 上 1 例であった. 甲状腺機能低下症患者の内分泌機能 検査成績を比較する目的で，ほぼ 同じ 年令層に 該当 し, 通常の内分泌機能検查や血液生化学的検查にて 異常が認められず，しかも骨成長が障害されている Achondroplasia 14例, Spondylo-Epiphyseal Dysplasia 10 例及び正常短軀者 3 例, 計 27 例を対照とし た(図1).

外観

甲状腺性侏儒症の特徵は，特有な顔貌，外観を呈 し，粘液水腫，低身長及び知能低下である，一般に稫 幹, 四肢の均衡は保たれているが, Wilkins のいう恥 骨結合を境界として身体を上節と下節に分けた比は, むしろ乳幼児期に近いことがわかる.

検査成績

検查項目は, 病歷, 生体の計測, 精神年令の判定及 び血液生化学的検查はもとよりであるが，今回は主と して内分泌機能検査, レ線検查所見について 検討し
た.

おむな内分泌検查成績を 表に 示した（表1). 甲状 腺機能成績をみると, PBI は $4 \sim 8 \mu \mathrm{g} / \mathrm{dl}$ を正常範 囲とすれば, 本症の平均值は $1.86 \pm 0.95 \mu \mathrm{g} / \mathrm{d} 1$, 分布 $2.0 \sim 4.8 \mu \mathrm{g} / \mathrm{dl}$ で対照群の $3.83 \pm 1.42 \mu \mathrm{g} / \mathrm{d} 1$, 分布 $2.1 \sim 8.0 \mu \mathrm{g} / \mathrm{d} 1$ に比べて明らかに減少している. 力 イ自乗検定法によって両群を比較してあ有意の差が認 められた. 血清コレステロールは 130～220 mg/dl を

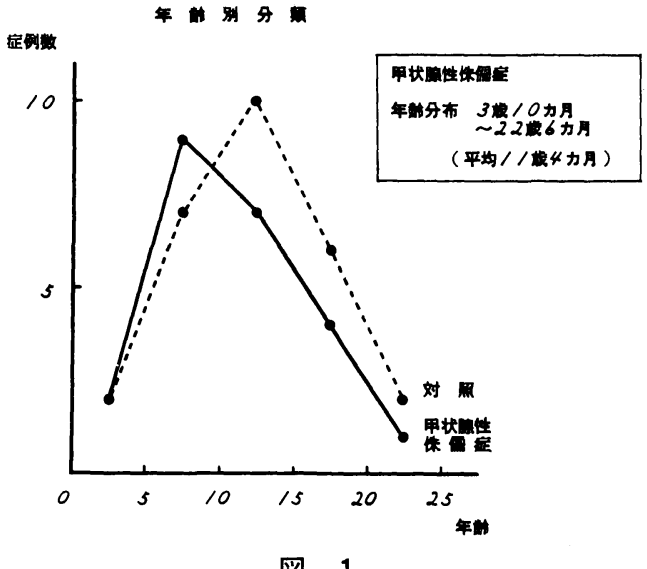

表 1 打むな内分泌機能検查成績

打すな状腺機能検查成績

\begin{tabular}{|c|c|c|c|c|c|}
\hline & & $\mathrm{PB} I \mu \mathrm{g} / \mathrm{d} 1$ & $\begin{array}{c}\text { 血清コレステ品 } \\
\text {-ルg/d1 }\end{array}$ & ${ }^{131} \mathrm{I}$ 摄 取率 & $\begin{array}{c}\text { TSH 試 } \\
24 \mathrm{~h}\end{array}$ \\
\hline 甲状腺性侏儒症 & $\begin{array}{lll}\text { 検 査 例 } & \text { 数 } \\
\text { 分 } & \text { 布 } \\
\text { 平 均 值 }\end{array}$ & $\begin{array}{c}18 \\
0.2 \sim 4.8 \\
1.86 \pm 0.95\end{array}$ & $\begin{array}{c}16 \\
139 \stackrel{\sim}{\sim} 389 \\
232.2 \pm 54.8\end{array}$ & $\begin{array}{c}14 \\
1 \stackrel{13}{\sim} \\
5.4 \pm 3.6\end{array}$ & $\begin{array}{c}13 \\
1 \stackrel{15}{\sim} 15 \\
6.2 \pm 4.5\end{array}$ \\
\hline 対 & $\begin{array}{l}\text { 検 查 例 数 } \\
\text { 分 } \\
\text { 平 均 值 }\end{array}$ & \begin{tabular}{l}
\multicolumn{2}{c}{24} \\
$2.1 \stackrel{2.0}{\sim} 8.83 \pm 1.42$
\end{tabular} & $\begin{array}{l}24 \\
118 \stackrel{246}{\sim} 246 \\
182.4 \pm 33.4\end{array}$ & $\begin{array}{c}21 \\
7 \stackrel{21}{\sim} 44 \\
18.4 \pm 8.7\end{array}$ & ${ }_{28 .} \stackrel{11}{\sim} 46$ \\
\hline
\end{tabular}

間脳一下垂体前葉機能検査成績

\begin{tabular}{|c|c|c|c|c|c|}
\hline & & 脸 波 & $\begin{array}{l}\text { 空腹時 } \\
\text { 血糖值 }\end{array}$ & $\begin{array}{l}\text { ブドウ糖 } \\
\text { 負荷試験 }\end{array}$ & $\begin{array}{l}\text { インシュ } \\
\text { リン負荷 } \\
\text { 試 験 }\end{array}$ \\
\hline $\begin{array}{l}\text { 甲侏 } \\
\text { 状儒 } \\
\text { 腺 }\end{array}$ & $\begin{array}{l}\text { 検查例数 } \\
\text { 正常例数 } \\
\text { 異常例数 }\end{array}$ & $\begin{array}{l}5 \\
2 \\
2\end{array}$ & $\begin{array}{r}13 \\
6 \\
7\end{array}$ & $\begin{array}{l}3 \\
2 \\
1\end{array}$ & $\begin{array}{l}3 \\
3\end{array}$ \\
\hline 性症 & $\begin{array}{c}\text { 異 常 率 } \\
(\%)\end{array}$ & 40 & 53.8 & $(33.3)$ & \\
\hline 対 & $\begin{array}{l}\text { 検查例数 } \\
\text { 正常例数 } \\
\text { 異常例数 }\end{array}$ & $\begin{array}{r}18 \\
11 \\
7\end{array}$ & $\begin{array}{r}21 \\
19 \\
2\end{array}$ & $\begin{array}{r}19 \\
18 \\
1\end{array}$ & $\begin{array}{r}18 \\
15 \\
3\end{array}$ \\
\hline 照 & $\begin{array}{c}\text { 異 }(\%) \text { 率 } \\
(\%)\end{array}$ & 38.9 & 9.5 & 5.3 & 16. 7 \\
\hline
\end{tabular}

下垂体一副腎皮質機能検査成績

\begin{tabular}{|c|c|c|c|c|}
\hline & $\begin{array}{l}\text { ソ } \\
\text { 試 } \\
\text { 験 }\end{array}$ & $17 \mathrm{KS}$ & $17 \mathrm{OHCS}$ \\
\hline \multirow{2}{*}{$\begin{array}{l}\text { 甲侏 } \\
\text { 状儒 } \\
\text { 腺 }\end{array}$} & $\begin{array}{l}\text { 検査例数 } \\
\text { 正常例数 } \\
\text { 異常例数 }\end{array}$ & $\begin{array}{l}7 \\
4 \\
3\end{array}$ & $\begin{array}{l}10 \\
10\end{array}$ & $\begin{array}{l}2 \\
2\end{array}$ \\
\hline & $\begin{array}{c}\text { 異 常 率 } \\
(\%)\end{array}$ & 42.9 & 100 & $(100)$ \\
\hline 対 & $\begin{array}{l}\text { 検査例数 } \\
\text { 正常例数 } \\
\text { 異常例数 }\end{array}$ & $\begin{array}{r}20 \\
17 \\
3\end{array}$ & $\begin{array}{r}24 \\
4 \\
20\end{array}$ & $\begin{array}{l}5 \\
3 \\
2\end{array}$ \\
\hline 照 & $\begin{array}{c}\text { 異 常 率 } \\
(\%)\end{array}$ & 15 & 80.8 & 40 \\
\hline
\end{tabular}


正常範囲とした．本症の平均值は $232.2 \pm 54.8 \mathrm{mg} / \mathrm{d} 1$ で, 対照群の $182.4 \pm 33.4 \mathrm{mg} / \mathrm{dl}$ に比べて増量して いる. ${ }^{131} \mathrm{I}$ 摄取率は 24 時間 $10 \%$ 以上を正常とした. 本症の平均值は $5.4 \pm 3.6 \%$ で対照群の $18.4 \pm 8.7 \%$ に比べて明らかに摄取率の低下を示し，しかも TSH 試験では本症の平均值 $6.2 \pm 4.5 \%$ に対して, 対照群 は 28.4土12.5\%と上昇を示した。すすなわち TSH 試 験にて， ${ }^{131}$ I 摄取率は対照群では反応して上昇する が，甲状腺機能低下症では反応し得ないということが できる，下垂体一副腎機能㭘査成績をみると，ソーン 試験では $50 \%$ 以下の落下率を示したのは，本症 7 例 中 3 例にみられ, 対照群の 20 例中 3 例に比して 異常 例が多いといえよう。 また 17一KS は本症 10 例に検 查を行なったが，その分布は $0.5 \sim 4.0 \mathrm{mg} / \mathrm{day}$, 平 均值 $1.4 \mathrm{mg} / \mathrm{day}$, 標準偏差は $\pm 1.2 \mathrm{mg} / \mathrm{day}$ であ り, 対照群の平均 $2.9 \pm 1.4 \mathrm{mg} /$ day に比して統計的 に低值を示し, 17一OHCS も症例は少ないが本症の測 定值は対照群に比して低い傾向である. 間脳一下垂体 前葉機能検查成績で, 脳波異常は本症 5 例中 2 例であ ったが症例が少なくて統計的な意義は少ない，空腹時 血糖値は $70 \mathrm{mg} / \mathrm{dl}$ 未満の低血糖值を示したものが本 症中 7 例, $53.8 \%$ に認められ, 対照群の $9.5 \%$ に比 べて有意の差を認めた。ブドー糖負荷試験, インシュ リン負荷試験をむ 3 例ずつ施行したが症例が少なくて 結論とならなかった．下垂体前葉そのものの機能検査 として, Human Growth Hormone (HGH と略す) の Radioimmunoassayによる測定が役立つことが報 告されている. われわれの $\mathrm{HGH}$ 測定は 1 例のみで あるが, 空腹安静時の $\mathrm{HGH}$ は $3.1 \mathrm{~m} \mu \mathrm{g} / \mathrm{m} 1$ であ り，インシュリン低血糖に対する $\mathrm{HGH}$ は最大值 3.2 $\mathrm{m} \mu \mathrm{g} / \mathrm{ml}$ で上昇しなかった. 岡田は甲状腺性侏懦症 8 例について検査した結果, インシュリン低血糖に対す る $\mathrm{HGH}$ の上昇反応は健康人上り有意に 低く，この うち 4 例には治療後も同様の 測定を行なって, $\mathrm{HGH}$ は増加したと述へている．とのととからも本症では機 能的な HGH 分泌障害すなわち機能的な下垂体前葉 機能低下が潜在しているといえよう.

\section{レ線学的所見}

レ線学的検査成績では，骨年令の遅延と分節状骨端 核 Punctuated Epiphyseal Dysgenesis (PED と略 す）が特徽的である. 手関節をみると, 相当の年令に 達しているのにかかわらず，手根骨々核や長管骨々端 核が出現しておらず，骨年令は著明に遅延している.
若年性甲状腺性侏儒症の手関節をみると，3才の時甲 状腺の手術を受けて以来成長が停止した症例では, 骨 年令は 3 才に止り, てれから手術時の歷年令を推定で きる. 従って骨年令を調べれば逆に本症の発症時期が 知机る. 股関節 $\mathrm{A}$ は 9 才の先天性甲状腺性侏懦症で, 大腿骨々核に両側性に明膫な PED を認める. 骨頭核 は生後 6 力月で出現するので, この症例は生後 6 力月 以前に甲状腺機能低下症が発症していなければならな い.このことから先天性甲状腺性侏懦症ではほぼ全例 にPED を認め得る.これに対し B は16才の若年性甲状

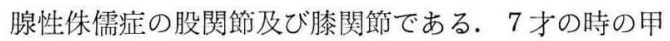
状腺手術を契機として発症したため, 大腿骨々頭核は 正常に発達しているが， 6〜 7才に出現する膝蓋骨々 核に PED の所見か認められる. 従っててれらレ線所 見からあ本症も発症時期を知ることができる(図 2 ).

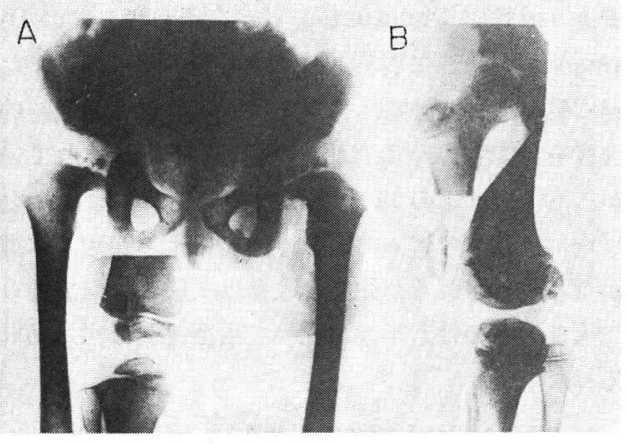

図 2 Punctuated epiphyseal dysgenesis のレ線所見
A. 先天性甲状腺性侏儒症 9 才
B．若年性甲状腺性侏儒症16才

治 療成績

長期間観察できたのは 5 例である. 甲状腺剂の投与 量や投与方法は幼児と比較的年長児とでは幾分異なる が，チラージン末 1 日 $0.01 \mathrm{~g}$ から開始し， 2〜3 週 間おきに増量して，最終的には 1 日 $0.1 \mathrm{~g}$ を維持量 としている. 症例によっては蛋白同化ホルモンを併用 した. 治療効果は当然, 身長の促進, 体重の增加, 知 能の改善, レ線学的な骨形成の正常化などに関して検 討すべきである. 5 症例について，身長・体重・骨年 令を相対的に比較してみると, 治療によりまず骨年令 の促進，ついで体重，身長年令の促進が認められた. 初診時 9 才 2 力月の先天性甲状腺性侏儒症の治療効果 を示す(図 3 ). 


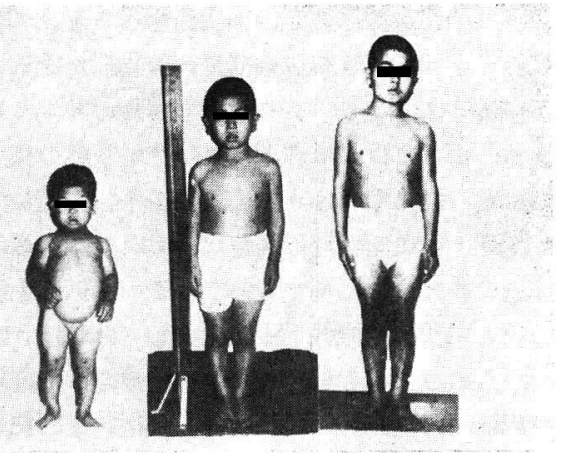

図3 治療効 果

$\begin{array}{llll}\text { 歴年 令 } & 9 \text { 才 } 2 \text { 力月 } & 11 \text { 才 } 5 \text { 力月 } & \text { 19才 } 4 \text { 力月 } \\ \text { 身長年令 } & 2 \text { 才 } 9 \text { 力月 } & 7 \text { 才 } 1 \text { 力 } & 10 \text { 才 } 3 \text { 力 } \\ \text { 骨年令 } 1 \text { 才 } & 9 \text { 才 } & 12 \text { 才 } 6 \text { 月 }\end{array}$

治療によりまず1才であった骨年令が急速に促進さ れ，治療前には出現していなかった大腿骨々頭核も治 療後 5 力月で Punctuated ながら現われ, この Dysgenesis も急速に改善され, 治療後 5 年では正常な形 態に修復されている，体重年令，身長年令の経時的な 推移を見ても，ともに比較的順調に促進されている が, 治療後 5 年の 14 才 4 力月で身長年令はなお 全国 平均にはかなり劣っている，治療により顔貌，体型は かなり改善されるが知能の改善は一般に困難であり， 先天性のものは若年性に比べて治療効果は劣る傾向で あった。

\section{考按と結 語}

甲状腺機能低下症に対するチラージン末の治療効果 は著じるしいものがあるが，本症の発症時期，機能低 下の程度, これに関連した下垂体機能の変化, 治療開 始時期, 更に治療法の工夫など多くの因子により治療 効果は左右される. 甲状腺ホルモンの作用機序とし て, Chondrogenesis と Osteogenesis の両者が一 般に報告され，甲状腺機能低下症においては機能的な $\mathrm{HGH}$ 分泌障害が存在し, 甲状腺ホルモンの投与によ って HGH 分泌を促進せしめるとの報告がある. Ray らは実験的甲状腺摘出ラッテの骨成長に及ぼす影響を 観察し, 成長ホルモンと, 甲状腺剂の併用療法がもっ とあ効果的であったと報告している. 甲状腺機能低下 症では Chondrogenesis, Osteogenesis ともに障害さ
れていることは事実であるが, 臨床例から潜在性下垂 体機能低下が証明されることから, Chondrogenesis の作用は下垂体を介した，いわば 2 次的作用と考えら れる.

\section{主 要 文 献}

1) Wilkins, L.: The diagnosis and treatment of endocrine disorders in childhood and adolescence. 1965.

2) Ray, R. D. et al.: Growth and differentiation of the skeleton in thyroidectomized hypophysectomized rats treated with thyroxin, growth hormone, and the combination. J. Bone \& Joint Surg., 56-A, 94-103, 1954.

3) 原田：臨床内分泌学. 南山堂, 1968.

4) 山本：内分泌機能の協関. 協同医書出版社, 1966.

\section{発 言 九州労災病院整形外科 川島 真人}

こういう症例では骨年令が重要な指標となるが骨年 令の判定法は，日本に於てもまだ完全なものがないわ けであり，私あ Tanner-Whitehous-Healy 法を導入 して従来の方法との比較検討を行なってきたが，やは り，まず正常な発育のレントゲン像を多く対照にと り，いくつかの骨年令判定法を行なってのち論ずるべ きと思う.

骨の発育年令は，正常であかなり variation があ るので, 正確な判定を行なう必要がある.

\section{解 答益田日赤病院 大橋 清秀}

今回は大和田法を用いて骨年令を測定した. $2 \sim 3$ の異なった測定法を併用して，総合的に骨年令を判定 することは特に乳幼児期の骨年令を正確に決めるのに 役立つと思う. 今後検討したい.

\section{発 言} 九州労災 天児 民和

骨系統疾患は病名に人名のついているあのが多いの で記憶し難く，種々な移行列も別の疾患として取扱わ れることああり，命名法を考えたり，それには多くの 症例を集めて整理するより解決の路はなく，地味な努 力が大切と思う。 